Dwi Nurhayati Adhani ${ }^{1}$

\title{
Peran Orang Tua terhadap anak usia dini (usia 2 tahun) yang mengalami Picky Eater
}

\begin{abstract}
Abstrak
Anak adalah berkah dari Tuhan yang menggembirakan bagi orang tua. Orang tua akan merasa berarti dan memiliki tujuan hidup jika telah hadir seorang anak. Seorang anak memiliki beberapa aspek perkembangan. Aspek-aspek perkembangan tersebut seharusnya dicapai dengan optimal. Perkembangan optimal dapat tercapai jika seorang anak medapatkan dukungan dari orang tua. Namun tidak semua anak memiliki kelancaran dalam perkembangannya. Salah satu hal yang dapat berpengaruh dalam perkembangan anak adalah Picky Eater. Picky eater adalah suatu kondisi dimana anak memilih-milih jenis makanan tertentu saja. Picky eater memiliki beberapa dampak diantaranya adalah stunting, tidak mandiri karena orang tua harus menyediakan makan yang sesuai dengan keinginan, mempengaruhi pertumbuhan fisik dan daya tahan tubuh anak. Hal ini memerlukan perhatian khusus sehingga perlunya peran orang tua untuk mengatasi picky eater pada anak usia dini agar anak dapat mencapai perkembangan yang optimal.
\end{abstract}

Kata kunci: Peran Orang tua, Picky Eater, Anak Usia Dini

\begin{abstract}
Children are a blessing from God that is pleasing to parents. Parents will feel meaningful and have a purpose in life if a child is present. A child has several aspects of development. These aspects of development should be achieved optimally. Optimal development can be achieved if a child gets support from parents. But not all children have fluency in their development. One of the things that can influence a child's development is Picky Eater. Picky eater is a condition in which children choose only certain types of food. Picky Eater has several effects including stunting, not being independent because parents must provide food that is in accordance with their desires, affecting their physical growth and endurance. This requires special attention so that the need for the role of parents to overcome picky eater in early childhood so that children can achieve optimal development.
\end{abstract}

Keywords: Role of Parents, Picky Eater, Early Childhood

\footnotetext{
${ }^{1}$ Prodi PG PAUD Universitas Trunojoyo,Madura Indonesia

Email:adhaniuwi@gmail.com
} 


\section{PENDAHULUAN}

Kehadiran anak adalah suatu berkah yang diberikan oleh Allah Swt. Anak akan memberikan tujuan hidup pada Ayah dan Ibu. Keluarga akan terasa lengkap dengan adanya tawa canda, serta tangisan dalam suatu kehidupan rumah tangga. Seorang anak akan memiliki pertumbuhan dan perkembangan yang optimal dipengaruhi oleh dua hal yaitu nature (bawaan) dan nurture (pola asuh, lingkungan)..

Perdebatan tentang yang paling banyak mendominasi pertumbuhan dan perkembangan anak antara nature versus nurture cukup menjadikan hal tersebut menjadi fokus utama. Nature (bawaan) adalah sesuatu yang dibawa seorang anak dari keturunannya seperti tampilan fisik, serta kepribadian. Sedangkan untuk nurture adalah gambaran lingkungan yang membentuk diri kita seperti pengalaman masa kecil, pola asuh dan peran orang tua, hubungan sosial, dan kebudayaan. Sebenarnya jika dilihat secara mendalam kedua aspek tersebut tidak dapat dipisahkan serta tidak dapat dilihat jumlah prosentase yang paling mendominasi, karena kedua aspek tersebut sama-sama saling mempengaruhi pertumbuhan dan perkembangan seorang anak.

Pertumbuhan dan perkembangan seorang anak dapat menjadi optimal adalah dengan melihat salah satu indikator dari kedua aspek tersebut (nature dan nurture). Hal yang menjadi fokus salah satunya adalah peran orang tua.Peran orang tua dalam hal ini tidak hanya memberikan dan mencukupi anak secara materi, namun orang tua juga harus ikut terlibat secara aktif untuk pertumbuhan dan perkembangan anak. Peran orang tua kepada anak yaitu memmenuhi kebutuhan anak di sekolah, mendampingi di saat belajar, memotivasi anak, menciptakan suasana belajar yang nyaman, perhatian dan kasih sayang, menanamkan budi pekerti

Peran orang tua juga merupakan kunci dari kesehatan anak. Anak yang sehat adalah anak yang memiliki tumbuh kembang secara normal. Peran orang tua yang terkait tumbuh kembang anak adalah melakukan Inisiasi Menyusui Dini, memberi ASI yang cukup, melakukan interaksi dengan anak dengan memberi senyuman, pelukan, penghargaan, bermain dan bernyanyi bersama. Tumbuh kembang seorang anak tidak hanya melalui jalan yang mulus dan mudah akan tetapi ada beberapa hambatan.

Anak-anak yang sehat adalah anak yang memiliki status gizi yang seimbang. Status gizi yang seimbang dapat dicapai dengan mengkonsumsi segala jenis makanan yang bergizi dan memiliki kadar karbohidrat, protein, lemak, dan vitamin yang cukup. Asupan makanan yang mengandung gizi sangat diperlukan untuk pertumbuhan , perkembang, memilihara kesehatan, dan menjaga kesehatan. Menjaga makanan yang bergizi juga penting dengan diimbangi olah raga yang cukup (Sudarsini \& pramono, kesehatan dan gizi anak usia dini, 2013).

Salah satunya hambatan anak tidak mencapai perkembangan dan pertumbuhan optimal karena mengalami picky eater. Picky eater adalah kebiasaan anak untuk melakukan pilih-pilih makanan dengan jenis tertentu serta melakukan penolakan makanan. Picky eater memiliki keterkaitan menyukai tekstur dan rasa makanan tertentu. Picky eater misal menolak makan nasi akan tetapi masih mau makan untuk olahan roti dan mie. 
Anak-anak yang mengalami picky eater memiliki karakteristik yaitu: suka mengeluh tentang makanan yang diberikan, tidak menyukai makanan seperti buah, sayur dan daging, melempar makanan yang tidak disukai saat makan, menyukai jenis makanan yang sama, tidak mau mencoba variasi makanan baru, makan lebih lambat, lebih menyukai makanan yang tidak sehat, seperti permen dan makanan berlemak, lebih memilih memakan snack, rewel dan marah-marah saat makan.

Adanya sensus yang dilakukan oleh World Health Organization adalah pada tahun 2015 terdapat data yaitu adanya kekurusan pada anak sekitar 14,3\% dengan total anak yang mengalami kekurusan yaitu 95,2 juta anak. Total tersebut termasuk penelitian tentang picky eater terjadi pada usia 2-4 tahun dan memiliki kemungkinan besar memiliki berat badan rendah dari pada anak yang bukan picky eater (Zuhrotul Eka \& M. Ali,2016).

Data lain tentang status gizi anak yang masih dibawah norma adalah pada tahun 2017 menurut Kemenkes bayi dengan rentang usia dibawah limtahun mengalami malsah gizi sekitar $17.8 \%$, dari data tersebut terdapat bayi dengan 3,8\% mengalami gizi buruk, dan $14 \%$ mengalami gizi kurang.

Data oleh kemenkes memperlihatkan terdapat 496 kabupaten/kota yang dianalisa, maka terdapat 404 kota yang memiliki masalah gizi yang kronis, 63 kota/kabupaten terdapat masalah gizi yang akut, dan 9 kota yang tidak ditemukan masalah gizi.

Penelitian lain yang telah dilakukan Sudibyo Supardi di National Institute of Health Research and Development pada anak usia dirta tahun 2015 memperlihatkan bahwa kesulitan makan sebesar 33.6\%, dan 44.5\% mengalami malnutrisi ringan, sedang. Selain itu terdapat $79.2 \%$ adanya data yang menunjukkan terdapat anak yang mengalami kesulitan makan lebih dari 3 bulan. Penelitian tersebut dilakukan pada anak usia 1-5 tahun dengan $43 \%$ anak yang mengalami gizi buruk.

Dampak anak yang memilih makanan (picky eater) ada beberapa macam yaitu karena anak memiliki jenis makanan tertentu maka ia memiliki kemungkinan untuk obesitas, karena ia cenderung memilih makanan yang memiliki lemak yang timggi dan tidak bergizi, anak yang picky eater memiliki kemungkinan perkembangan mental yang lebih rendah 14 point dari anak yang meiliki kecukupan gizi, dan juga jika anak mengalami pemilihan jenis makanan tertentu maka kemungkinan besar anak mengalami sembelit kronis.

Dampak lain adalah anak yang picky eater ditandai dengan adanya gangguan selama masa pertumbuhan dengan memperlihatkan berat badan, tinggi badan yang kurang serta memiliki kesulitan dalam meningkatkan berat badan. Picky eater menyebabkan anak mengalami asupan gizi yang terbatas sehing berdampak pada pertumbuhan dan perkembangan yang lambat (Zuhrotul Eka \& M. Ali,2016)

Dari paparan diatas maka pentingnya peran orang tua di rumah untuk mengatasi anak yang mengalami picky eater. Jika dilihat lebih dalam cara pemilihan anak serta perilaku makan anak perlu ditangani lebih serius karena akan berdampak pada pertumbuhan dan perkembangan 


\section{METODOLOGI}

Penelitian ini merupakan penelitian kajian pustaka digunakan untuk mengkaji, menelaah dan juga sebagai dasar penguat dari penelitian yang akan diadakan. Apakah penelitian itu bernilai ataukah tidak biasanya dapat dilihat dari seberapa jauh dan seberapa runtut kajian pustaka yang disusun oleh peneliti.

Berkaitan dengan hal itu, Nazir (2005: 93) menyatakan bahwa studi kepustakaan atau studi literatur, selain dari mencari sumber data sekunder yang akan mendukung penelitian, juga diperlukan untuk mengetahui sampai ke mana ilmu yang berhubungan dengan penelitian telah berkembang, sampai ke mana terdapat kesimpulan dan generalisasi yang pernah dibuat sehingga situasi yang diperlukan diperoleh.

\section{PEMBAHASAN}

\section{Definisi Anak Usia Dini}

Anak usia dini adalah seorang anak dalam masa rentang usia 0-6 tahun dengan melewati usia bayi, batita dan masuk pada usia prasekolah. Setiap masa yang dilaluinya memiliki karakteristik yang khas seperti pada masa bayi, batita, serta pada masa prasekolah. Pada perkembangan tersebut dalam berlangsung dengan normal sehingga tidak mengakibatkan kelainan pada anak ( Novan Ardy wiyani, 2016).

Definisi yang lain adalah anak usia dini merupakan seorang manusia yang memiliki suatu potensi yang perlu dikembangkan. Anak dengan karakteristik tertentu serta tidak sama dengan orang dewasa, dengan ditandai anak yang aktif, dinamis, antusias, serta ingin tahu untuk mengeksplorasi lingkungan sekitar untuk belajar (Didith Pramunditya Ambara, et al, 2014).

\section{Perkembangan}

Perkembangan merupakan suatu deretan yang progresif, dari perubahan yang teratur serta koheren. Progresif maksudnya perubahan menunjukan arah yang jelas, bibingan anak untuk maju, sedangkan teratur dan koheren maksudnya memperlihatkan hubungan yang nyata antara perubahan yang terjadi serta yang telah mendahuluinya serta mengikutinya (Novi Mulyani, Perkembangan Dasar Anak Usia Dini.,2018).

Perkembangan merupakan suatu perubahan dengan pendekatan kualitatif. Hal tersebut ditandai dengan adanya perkembangan bukan hanya penambahan secara sentimeter $(\mathrm{cm})$ pada tinggi seorang anak namun juga adanya penambahan kemampuan seorang anak, fungsi kompleks dari banyak struktur (Hurlock, 2009).

\section{Pertumbuhan}

Pertumbuhan merupakan semua hal yang berkaitan dengan adanya perubahan tubuh seorang anak serta dapat diamati secara fisik, seperti perubahan fisik, peningkatan jumlah sel, ukuran, kuantitatif, tinggi badan, strutur tulang dan gigi, berat badan ((Hurlock, 2009).

\section{Definisi Picky Eater}

Picky eater sebenarnya perkembangan normal seorang anak akan tetapi terlihat adanya fluktuatifnya selera, adanya genetik, dan perilaku makan seorang individu. Picky eater tidak banyak memakan makanan walaupun mereka lapar. Mereka lebih memilih 
makan dengan rasa yang manis sehingga ditangani dengan tidak tepat (Maryan Jacobsen, 2014).

Picky Eater adalah saat anak lebih memilih makanan yang sama untuk setiap kali makan, sehingga anak merasa nyaman dengan makan yang sudah menjadi kebiasaan dan malas mencoba makanan yang baru (Sandra Fikawati, 2007).

\section{Peran Orang tua}

Orang tua memiliki suatu pengaruh penting dalam kehidupan anak. Peran orang tua sangat penting untuk kehidupan anak dengan melakukan hal-hal seperti ini: Memberikan anak waktu yang lebih untuk berkumpul, memberikan anak lingkungan yang mendukung di rumah, memberikan anak semangat, menjalin jaringan dengan guru sekolah, mendiskusikan masalah anak bersama-sama, mengawasi aktifitas anak, meningkatkan kebiasaan belajar anak, menyeimbangkan sikap ketika menasehati, menjadi orang tua yang kreatif.

\section{Peran Orang tua Anak yang mengalami Picky Eater}

Peran orang tua untuk menghadapi anak yang mengalami picky eater adalah dengan cara berikut (Khusnul, AK.2019):

1. Saat anak memperlihatkan reaksi tidak menyukai suatu makanan serta meludahkan makanan, maka orang tua disarankan untuk menghentikan pemberian makan tersebut, karena jika memberikan maknan yang sama makan anak akan memperlihatkan perilaku menolak, adanya rasa takut, serta menolak makanan. Pemberian waktu dengan makanan yang sama sebaiknya diberikan jeda serta dicampur dengan maknanan yang disukai.

2. Saat anak menunjukkan rasa ketakutan untuk mencoba makanan yang baru maka diet anak menjadi lebih terbatas, anak hanya makan dengan porsi yang sedikit dan akan bosan jika melihat menu yang sama, maka orang tua perlu untuk memberikan siklus menu

3. Menghindarkan anak untuk pemberian snack diluar jadwal makanan tambahan

4. Anak perlu membiasakan diri makan bersama dengan keluarga di meja makan

5. Jangan menyuapi anak dengan paksaan

6. Membiarkan anak untuk memilih maknan dengan preferensi atau mengajak anak untuk membeli bahan makanan kemudia mengolah makanan sendiri

7. Orang tua seharusnya mengikuti keinginan nak sesuai dengan menu yang disukai, karena adanya kemungkinan ketidaksukaan terhadap menu tertentu karena ingin menentang orang tua.

\section{KESIMPULAN}

Pertumbuhan dan perkembangan anak usia dini agar optimal memerlukan fokus yang besar dari orang tua. Orang tua perlu memberikan semua perhati pada aspek terkecil perkembangan seorang anak. Perkembangan dan pertumbuhan seorang anak sangat terkait dengan pemberian nutrisi yang cukup. Hal tersebut tidak akan tercapai jika seorang anak mengalami picky eater sehingga anak hanya memilih-milih makanan dengan variasi tertentu serta enggan mencoba makanan yang baru, bahkan menghindari 
makanan seperti buah dan sayur. Maka dari itu perlunya petran orang tua untuk memberikan perhatian terhadap pola makan anak dengan tidak memaksa anak saat anak muntah/meludahkan, memberika siklus menu harian, mengkombinasikan makanan yang disukai dan tidak disukai, mengajak anak untuk terlibat dalam mengolah bahan makanan tertentu, kemudian menyajikan, melakukan pembiasan untuk mekan di meja makan sehingga dapat berkumpul bersama keluarga, tidak memberi sncak saat anak belum makan makanan inti.

\section{DAFTAR PUSTAKA}

Ambara, DP. 2015.Asesmen anak usia dini. Yogyakarta: Penerbit Graha Ilmu http://femaleradio.co.id/female-info/female-lifestyle/3240-peranan-orang-tua-dalammendukung-pendidikan-anak, diakses tanggal 8 Maret 2019, pukul 12.00 http://www.depkes.go.id/article/print/201408120001/orang-tua-kunci-utama-tumbuhkembang-anak.html, diakses tanggal 8 Maret 2019, pukul 13.10

http://www.depkes.go.id/article/view/16032200005/tahun-2015-pemantauan-statusgizi-dilakukan-di-seluruh-kabupaten-kota-di-indonesia.html, diakses tanggal 8 Maret 2019, pukul.10.50

http://www.idai.or.id/artikel/seputar-kesehatan-anak/pilih-pilih-makanan, diakses tanggal 8 Maret 2019, pukul 8.20

https://cintalia.com/kehidupan/orang-tua/peran-orang-tua-dalam-mendidik-anak, diakses tanggal 8 Maret 2019, pukul 15.55

https://databoks.katadata.co.id/datapublish/2018/04/05/178-balita-indonesiakekurangan-gizi, diakses tanggal 8 Maret 2019, pukul 10.03

https://hellosehat.com/parenting/nutrisi-anak/dampak-anak-suka-pilih-pilih-makan, diakses tanggal 8 Maret 2019, pukul 11.05

https://lifestyle.kompas.com/read/2018/10/06/081840520/pengaruh-pola-makan-pickyeater-pada-kesehatan-anak, diakses tanggal 8 Maret 2019, pukul 11.10

https://www.verywellmind.com/what-is-nature-versus-nurture-2795392, diakses tanggal 8 Maret 2019, pukul 16:22

Hurlock, Elizabeth.Perkembangan Anak Jilid 1. Terj.Meitasari, (Jakarta : Erlangga)

Khumairoh, AK. 2019.Dampak anak yang mengalami Picky Eater. Skripsi . PG PAUD Universitas Trunojoyo Madura.

Maryan Jacobsen.2014. From Picky To Powerfull, The Mindset Strategies and Know How You Need To Empower Your Picky Eater, (California: RMI Books, 2014)

Mulyani,Novi. 2018. Perkembangan Dasar Anak Usia Dini.Yogyakarta: Gava Media Sandra Fikawati, Gizi Anak dan Remaja.2007. (Depok: Rajawali Pers)

Sudarsini \& Pramono. 2017.Kesehatan dan Gizi Anak Usia Dini. Malang:Universitas Negeri Malang

Wiyani Ardy Novan. 2016. Cetakan ke II. Buku AJAR Penanganan Anak Usia Dini Berkebutuhan Khusus, Yogyakarta: Ar-Ruzz Media

Zuhrotul Eka \& M. Ali, “Analisis Pilih-Pilih Makan Pada Anak Usia 1 Sampai 3 Tahun Di Desa Suci Kabupaten Jember", Jurnal Pengabdian Masyarakat Ipteks, Vol. 2 No. 2 Desember 2016, hlm.84 